\title{
Touring, Women, and the English Professional Stage
}

Although they have not been widely recognized as such, the significant number of surviving records which document the careers of itinerant women performers in England reveal nothing less than a tradition of female participation in the professional theatre before $1660 .{ }^{1}$ Despite the exclusion of women from the commercial stages of London, the records indicate that touring women performers were acknowledged as professional entertainers, licensed by the state to perform, and paid for their performances in cities, towns, and households across the country. Recent criticism has begun to address the omission from scholarship of women's engagement in England's professional performance culture; yet the records, the primary source of itinerant women's performances, present considerable interpretive and methodological challenges which remain to be addressed. ${ }^{2}$ This article does participate in ongoing efforts to recover evidence of professional women's theatrical labour before 1660 , a project which is, by necessity, positivist. Because we cannot quantify the performances of itinerants, because the remaining records cannot be taken as a representative sample of what occurred, and because the records themselves are slippery, biased, and grounded in the time and place of a single instance, I question strictly positivist approaches to reading the archives. The existing records are important because they document a tradition which would otherwise be lost, but they cannot be assembled into an uncomplicated, straightforward history. While a strictly quantitative analysis cannot possibly recover the full scope of itinerant practice, I argue that the records provide an opportunity for qualitative analysis. Indeed, a method of reading the records which pairs a positivist approach with one that acknowledges the ambiguous, site-specific, and temporal nature of each individual dramatic record both recovers the labour of women theatre professionals and has the potential to reveal the politics of individual performances. By examining some of the extant records of itinerancy using a positivist methodology, then outlining the limitations of using this approach alone to understand 
dramatic records, and finally concluding with a test case — the records documenting the career of a 'french woman that had no hands' - I demonstrate that performance records can recover women itinerants as performers whose theatre could be just as politically challenging as their liveried male counterparts.

\section{Positivism and the Records of Women Itinerant Performers}

Pathbreaking work by Thornton Shirley Graves, Ann Thompson, and James Stokes has outlined some of the records of itinerant women performers, but as of yet there are no accounts in scholarship which examine a wide variety of women itinerant performers exclusively, which consult a sampling of records from a large geographical area, or which use records from more than a limited number volumes from the Records of Early English Drama. The paucity of scholarship on itinerant performers stems, at least in part, from the difficulty of obtaining records of their performances, especially before the inception of REED. The performances of itinerants were largely unscripted, and if they were scripted, these documents have not survived; most of the records of itinerant performers are found in civic record books, broadsheets, ecclesiastical court records, household account books, diaries, and licenses from the Master of the Revels to perform. All of these documents have survived inconsistently, and all of them were very difficult to access before REED. But even twenty-nine years after the publication of York, the first REED volume, the difficulties of using REED as well as scholarly inattention to its wealth of resources has continued to prevent scholars from fully realizing and recognizing the rich tradition of women's itinerancy. ${ }^{3}$ Although REED's volumes publish documents relating to itinerancy (indeed, this article would be impossible without REED's achievement), their bias favours the study of liveried troupes, especially on REED's companion website, Patrons and Performances, where one can only search records by patron, event, venue, or troupe, none of which are usable search terms for itinerant performers who did not have patrons and were not, accordingly, part of a troupe named for their patron. ${ }^{4}$ Despite the neglect of the records of itinerancy and the difficulty of obtaining and reading performance records both before and after REED, a quantitative examination of the records which do remain of women's itinerant performances makes it clear they were an important part of the theatrical culture of the towns and households of early modern England. 
Within the extant records, it is clear that women performed frequently and in a large number of venues. In fact, the records suggest that women professional performers were neither rare nor significantly more culturally unacceptable than their male counterparts. For instance, in Henry Farley's $S t$ Paules-Church her Bill for Parliament (1621), Farley includes an anti-theatrical complaint which rails against the popularity — and financial success — of the various kinds of theatre available to the early modern English spectator:

To see a strange out-landish Fowle, A quaint Baboon, an Ape, an Owle, A dancing Beare, a Gyants bone, A foolish Ingin move alone, A Morris-dance, a Puppit play, Mad Tom to sing a Roundelay, A Woman dancing on a Rope, Bull-baiting also at the Hope; A Rimers Iests, a Iugglers cheats, A Tumbler shewing cunning feats, Or Players acting on the Stage, There goes the bounty of our Age:

But unto any pious motion,

There's little coine, and less devotion. $(\mathrm{A})^{5}$

In Farley's poem, the performance of a woman professional entertainer does not merit shock. Instead, the rope dancer is included amongst a long list of performers, from an 'out-landish Fowle' to 'Players acting on the Stage' on whom, Farley argues, the populace wastes its money. Performance records from account books similarly reveal the commonplace nature of women performers in the culture; they were permitted to and banned from performing with the same frequency as their male counterparts, and they were paid for their work as well. For instance, Joyce Jeffries's account book for the years 1639-40 records payments to the following entertainers:

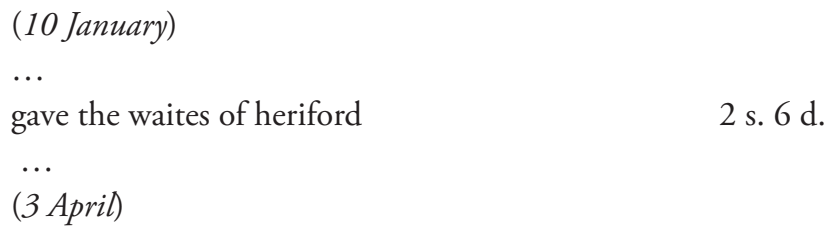




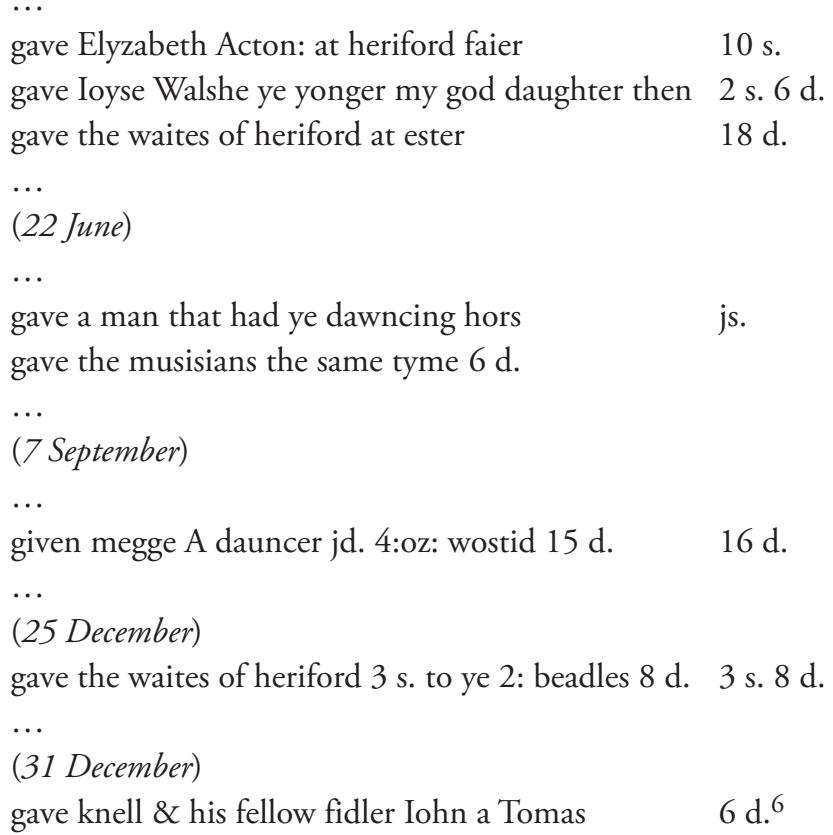

Jeffries's account book, preserved at the British Library, lists her expenses for each quarter in a matter-of-fact way. Her description of the performance of Meg the dancer does not differ qualitatively from her description of the male fiddlers who played for her at the New Year. Meg was paid less for her performance than the man with the dancing horse, but there are so many possible explanations for why this may be the case that it goes too far to assume it has anything to do with her gender. Jeffries's manner of record keeping is entirely typical, and the ordinary status of a women performer in Jeffries's account book is further evidence that women's performances were ordinary events.

Women participated in every facet of touring. The extant records demonstrate that women performed alone, with their husbands, and with troupes. For example, a record from Norwich from 14 March 1638 indicates that 'ffrancis Stolly brought into this Court alycence for him his wife and assistance to shewe sundry storyes with slight of hand Dated xxo Septembris 1637 to hold for a yeare, they haue leave to shewe till Satterday night next, and noe longer.' 7 Similarly, Herbert granted 'A license to Thos. Barrell with one man his wife $\&$ children to toss a pike for a yr. $20^{\text {th }}$ Augt. $1622-10 s^{\prime} .{ }^{8}$ A number 
of women involved with animal acts were licensed and performed widely as well. Stokes records evidence of a man and wife team who traveled with their dancing horse. ${ }^{9}$ In 1623, a license was issued to 'Marke Bradley with his wife to make shewe of a Ramme with 4 horns for a year'. ${ }^{10}$ And William Smith and his wife Jane were licensed with their two assistants 'to show a birde called a Starr for 6 months'. ${ }^{11}$ Some licenced women performers are easily subsumed into the category of freak performers or are revealed as profiteers from the display of freak performers. ${ }^{12}$ A record from Norwich shows a woman involved in marketing and displaying a freak performer with her husband:

This day Thomas wyatt \& Ioane his wife brought into this Court A lycence dated the xxvj ${ }^{\text {th }}$ of June last vnder the hand \& seale of George Buck knight maister of the Revelles for the shewynge of one Peter williams a man monstrously deformed And he hath liberty to shew him this present day $\&$ no longer. ${ }^{13}$

In an entry in his diary from 11 July $1630-1$, Sir Thomas Crosfield lists the types of entertainment available during Oxford's 'Act' of that year, the only time that players and itinerants were permitted. ${ }^{14}$ His list of 'Things to be seene for money in ye City', include:

1. Playes: 2. dancing vpon ye Rope $\&$ vaulting upon ye Sadle. 3. virginalls $\&$ organs playing by themselves 4 . a dutch-wench all hairy $\&$ rough vpo $n$ her body. 5 . The history of some parts of ye bible, as of ye creation of ye world, Abrahams Sacrificing his Sonne, Nineveh beseiged \& taken, Dives \& Lazarus. 6. The dancing of ye horse at ye Starre. ${ }^{15}$

The woman Crosfield describes was likely Barbara Urslerin, who had a long career as a freak performer and a harpsichordist in both England and Europe. ${ }^{16}$

All of the performers listed above were licensed by the Master of the Revels to perform. While the liveried all-male troupes like the Queen's men needed noble and, after 1603, royal patents as well as a license from the Revels office to perform, itinerants needed only a license from the Revels office, issued annually or biannually. ${ }^{17}$ Licenses were necessary because of the 1572 Act for the Punishment of Vagabonds and for the Relief of the Poor and the Impotent, legislation which was the culmination of centuries of efforts to contain vagrancy. ${ }^{18}$ The act determined that a vagabond was a person of more than fourteen years old who was 
whole and mighty in body and able to labour, having not land or master, nor using any lawful merchandise, craft, or mystery whereby he or she might get his or her living, and can give no reckoning how he or she doth lawfully get his or her living. And all fencers, bearwards, common players in interludes, and minstrels not belonging of this realm to any baron or towards any other honourable personage of greater degree. ${ }^{19}$

As often as this act is quoted, it is rarely mentioned that performers of both genders are considered in the statute, indicating a tradition of professional female performance. Formally legislated under Elizabeth, the practice of regulating playing only increased under the Stuarts, who consistently centralized the censorship of all theatrical activity in the country. Sir Henry Herbert, Master of the Revels from 1623 to 1673 , enthusiastically embraced the licensing of itinerants, according to Bawcutt 'probably more from a wish to maximize his income than from a desire to assert an ideological hegemony over the drama' ${ }^{20}$ While Herbert's motives might have been mostly pecuniary, his licensing of all manner of acts and support of their right to play also was informed by an anti-Puritanical support for theatre. Herbert even went so far as to issue an arrest warrant for John Platt, a constable from Warre, because he prevented 'players to show there beeing lycensed by Sr Henry Herbert Knt' in $1631 .^{21}$ Despite all of the efforts to license performers, entertainers could and did perform without a license despite the threat of punishment.

The licensing of players and itinerants was important because it transformed a marginal group — players and itinerants — from unlawful vagabonds into representatives of the state. ${ }^{22}$ As Peter Greenfield writes on the cultural logic of licensing and noble-sponsorship,

Without the license and livery of their patron, the players appeared to be masterless wanderers, the sort of men thought to be the greatest threat to the social order by aristocracy and civic magistracy alike. The players' visit to a town provided a temporary escape from the unchanging regimen of work, and of familial and civic duties, imposed by the social order. More dangerous was that the players themselves represented a life of constant festival, of freedom from authority of master, guild, and city, of freedom to determine one's own time, movement, and actions. The players' appearance in town could hardly help reinforcing the desire of the powerless for such freedom, thereby arousing their discontent with the dominant social order, even though that discontent might be expressed only as 
temporary enjoyment of freedom, rather than any concerted attempt to change their status. ${ }^{23}$

Greenfield's account does not include — or even acknowledge — other kinds of touring performers. By Greenfield's logic, itinerant performers, who were always unliveried, would be perceived as impossible threats to the social order. Yet in plain fact they were licensed and permitted to perform. To the extent that an itinerant performer played at the behest of a given town's Mayor or the head of a household, they were subject to the same kind of containment Greenfield describes affecting liveried players. ${ }^{24}$ Although itinerants did not have noble sponsorship in the way that the liveried troupes did, the process of licensing can be seen to do the same work of containing their politically explosive difference and making them into servants of the state. Moreover, the subversion/containment model Greenfield asserts probably did not work so neatly. The temporality of performance gives it a potential that could easily, if momentarily, disrupt the containments of livery and/or licensing.

To the extent that it contained the subversion of travelling performers, licensing made women performers into acceptable servants of the state. Because Herbert's office book no longer survives, English licenses issued to performers or players of any kind are extremely rare. ${ }^{25}$ Of the seven remaining licenses of itinerant performers, all of which are printed in N.W. Bawcutt's The Control and Censorship of Caroline Drama: The Records of Sir Henry Herbert, Master of the Revels 1623-73, two of the licenses name women performers. The first was issued to the Jones family in 1630. In the license, Herbert directs all

Mayors Sheriffes Iustices of the peace Bayliffes $\mathrm{Co}<\ldots>$ and all other his ma ${ }^{\text {ties }}$ officers true Liegemen and subiectes ... [that he has] by these $\mathrm{p}<$ rese $>$ ntes lycenced and authorised Iohn Iones Anne his wief Richard Payne Richard Iones and their assistance To sett forth and shewe $<\ldots .>$ Motion $w^{\text {th }}$ dyvers storyes in ytt As alsoe tumbleing vaulteing sleight of hand and other such like feates of Activety Requyreing you and eu<er>y of you ... p $<$ er>mytt the said Iohn Iones Anne his wief Richard Payne Richard Iones and their assistantes quietly to passe and to try their said shewes $\mathrm{w}^{\text {th }}<\ldots$. $>$ Trumpettes as they or any of them shall think fitteing for the same from tyme to tyme and at all tyme $\&$ tymes $\mathrm{w}^{\text {th }}$ out any of yor letts or molesta $<$ cons $>\mathrm{w}^{\text {th }}<\ldots>$ places of Iurisdiccon Townes Corporate Citties or Buroughes whatsoever $\mathrm{w}^{\mathrm{th}} \mathrm{n}$ the Realm of England. ${ }^{26}$ 
Herbert's strong language in support of the Jones's right to perform is indicative of the struggle between the Revels office and the increasingly Puritanical town authorities who were resistant to the disturbances of performances. In the license, the Jones family are authorized by the crown to perform; prohibiting their performance constitutes a violation of the king's will. Moreover, although Anne Jones alone is defined by her relationship to her husband, her presence is not highlighted as something exceptional. She is an accepted member of the troupe.

The second extant license that affirms a woman's performative legitimacy was granted to Sisley Peadle on 29 August 1631. In the license, Herbert states that

I haue by these $\mathrm{p}<$ rese $>$ ntes Licensed and authorized Sisley Peadle; Thomas Peadle her sonne Elias Grundling and three more in theire Company to vse and exercise Daunceing on the Roapes, Tumbling, Vaulting and other such ffeates which they or any of them are practized in or can performe Requireing you and euery of you in his Ma: ${ }^{\text {ties }}$ name to suffer and $\mathrm{p}<\mathrm{er}>\mathrm{mitt}$ them ... quietly to passe and to sett forth and shewe those things before menconed $\mathrm{w}^{\text {th }}$ such musicke Drume or Trumpetts as they shall thinke fitting for the same ffrom time to time and att all time and times $\mathrm{w}^{\mathrm{th}}$ out any of your Letts or molestacions $\mathrm{w}^{\text {th }}$ in any of your Liberties and place of Iurisdiccon ... and alsoe to be ayeding and assisting vnto them if any wrong or Iniury shall be offered vnto them or any of them They behaueing themselues honestly and according to the Lawes of this Realme and forbearing to make shewe on the Saboth day Or in the time of Devine service you affording them your Townehalls, Mootehalls, Guildhalls or some convenient place to shewe. ${ }^{27}$

The remainder of the license issued to Peadle warns town officials not to allow any unlicensed performers, to strip unlicensed performers of their suspect or outdated licenses, and to imprison them. Similar to his use of the Jones license, Herbert uses Peadle's license to stake out his authority over town governors, indicating that their refusal to let Peadle perform constitutes a violation of the king's wishes. Sisley Peadle's name is the first on the license, so it is reasonable to infer that she was in charge of the troupe and responsible for its business. Her performative role in the troupe is unclear, but so are the roles of all the people mentioned in the license. Both Bawcutt and Philip Butterworth note the long career of the Peadle troupe which included at least two generations of performers whose careers extended between 1609 or earlier and $16399^{\prime}{ }^{28}$ Earlier documents relating to the troupe do not indicate 
that Sisley Peadle always had such a prominent role; instead, William Peadle, who was likely her husband, appears to have been its leader. ${ }^{29}$ By 1631, it seems, Sisley Peadle had taken over from her husband, whose name does not appear in the 1631 license. At the head of a successful and long-lasting troupe, Peadle comes across as a business woman who performed with the authority of the king's license behind her.

The possession of a license, of course, was no guarantee that one would be allowed to perform. For instance, on 27 September 1614

Ciprian de Roson with his wife \& two assistantes who shewed forth A lycence vnder the seale of the Master of the Revelles authorisinge them to shewe [forth] feates of actiuty together with A beast Called an Elke nowe enionyned to depart the Cytty this present day vppon payne of whippynge. ${ }^{30}$

Furthermore, some players did not appear to have licences at all, or offended town authorities to such an extent that they were punished. In Norwich on 13 September 1600 'William Nynges his wife was Commaunded that neyther he nor his wife shall singe nor sell any Ballettes within this Cytty after this day upon payne of whippynge. ${ }^{31}$ Stokes records evidence of Thomas Houlder and Barbara Browning who were cited in the court records in Westbury in 1603 because 'They did play the mummers by night, and hee ware her clothes and she ware his' ${ }^{32}$ In West Thorney, 'Thomasine Bonny was sought ... for dauncing in mans apparell'. ${ }^{33}$ Despite records like these, there is no evidence to support Michael Shapiro's supposition that 'provincial theatrical troupes may have anticipated that traveling with women would jeopardize their ability to secure the permission they needed ... to perform'. ${ }^{34}$ Instead, women performers seem to be refused permission with no greater frequency than their male counterparts. Indeed, in their introduction to REED: Somerset, Stokes and Alexander note that women were not permitted to perform in that county for reasons having to do with problems with their licenses and their insufficient respect for religious devotion rather than for their sex. ${ }^{35}$

Household account books and church burial records are also good repositories of records of touring performers. The Household Accounts of Edward Stafford, Duke of Buckingham from 1520-1 record the following payment:

Item in Rewarde geven by the said Dukes coimmaundement vnto certain frenshe men and ij frenshe women playing afore the said Duc the passion of oure lorde by 
a vise and also to a yong maide a Tumbeller by Reaport of Iohn kyrk being present maister poley. 36

The household book of John, first Viscount Scudamore in 1642-3 on the 29 December records a payment for music to 'a man $\&$ a woman'. ${ }^{37}$ Joyce Jeffries's account book records her patronage of both male and female performers. In 1638-9, several payments to female performers were made, including payments to 'Mrs mary wallwin, mary powell \& fidler', 'Elyzabeth Acton to give the musick at Master Aldermans at the play', and Meg the dancer, who has already been discussed. ${ }^{38}$ Finally, the St Mary Parish Register in Eccles refers to 'Ellen Thropp, called Mr Atherton's fool' who was buried 27 October 1616. ${ }^{39}$ Household account books, as Barbara Palmer has discussed, have barely been touched as a resource; examining these archives can only recover more evidence of itinerant women's performances in this venue. ${ }^{40}$ Remarkable as all of these records are, and as clearly as these records reveal women's imbrication in the professional performance culture of early modern England, the inadequacies of the documents compromise positivist attempts to analyze them.

\section{The Limitations of Positivism}

The limitations of the remaining evidence of itinerant women performers are numerous. The records of itinerant performers necessarily represent only a trace of actual practice because of the improvisational and frequently nontextual nature of their performances. Although some broadsheets survive which reveal details about the acts of some freak performers, for most of the performers of whom records are extant, no text remains except for the performance records themselves. ${ }^{41}$ What is more, a record which describes the performance of an individual in one locale cannot be taken to represent what every performance by that performer might have been like. A record cannot stand as a representative sample of the career of a given itinerant. And there are relatively few itinerants for whom multiple records survive.

The ways in which dramatic records were produced in early modern England further complicate the body of records that were written in the first place. Andrew Gurr's 'The loss of records for the travelling companies in Stuart times' suggests that players in this period 'were regularly visiting towns and playing at inns as a matter of routine without first securing leave from the mayor, or at least receiving any payment, so that the accounts take no 
note of them'. ${ }^{42}$ Gurr notes that with the increased power of the Master of the Revels mayors were no longer required to act as censors as they had done under Elizabeth:

Although the civic authorities did continue to grant permission for companies to give performances in their municipalities for some decades after 1603, it is not easy to see whether in doing so they were simply hanging onto a by then longrunning practice, or more positively clinging to their privilege of controlling the plays to be offered to their citizenry in spite of the centralised controls that now existed. Under James, with the Master of the Revels taking over censorship and licensing of plays they soon gave up the privilege of a mayoral performance for censorship purposes, but they did try to retain the authority to allow performing for only a limited time in their own territory. ${ }^{43}$

Critics usually see the decline in records of performances in Caroline England as evidence of a decline in touring in the face of growing Puritanical influence over town authorities. ${ }^{44}$ Gurr's argument asserts just the opposite: that touring increased during these years because there was nothing the town authorities could do to stop performers from playing. There are, of course, no records in civic documents of performers who did not bother to seek the permission of the town to perform. As a result, Gurr argues, the civic records that do exist are distorted since they contain only the authorities' attempts to contain or ban playing. The records are not evidence of a decrease in playing but instead are evidence of an increasingly futile attempt to legislate a practice that no longer required their approval. ${ }^{45}$ The implications of Gurr's reading of trends in Stuart and Caroline civic record-keeping for itinerant performers are tremendous, since such records are a primary source of their performances. Furthermore, if Gurr's hypothesis is correct, then itinerant performers had enough status with their licenses from the Master of the Revels to perform without town permission and avoid arrest. Paradoxically, it is likely that the more itinerants performed, the less we hear of them.

The complications arising from the nature of itinerant performance and the vagaries of Stuart record-keeping are only intensified by the inconsistent survival of the records. The extant licenses issued by the Revels office, for example, are limited in number and cannot be said to bear any relationship to the extent of itinerant performances in the period. The number of surviving licenses are so limited because Malone and other early editors of the office book of Sir Henry Herbert were uninterested in the kinds of theatre per- 
formed by itinerants and recorded few details about them. ${ }^{46}$ The omissions of these early scholars combined with the fact that Herbert's office book was lost means that our knowledge of the scope of itinerant performance will never be complete. Their omissions began the tradition of privileging the printed playtext over the performance record and helped promulgate a sanitized version of Renaissance drama that emphasizes the plays of the Shakespearean stage over the popular non-textual theatre of itinerant performers.

Additionally, the inherent ambiguities within the extant documents that record itinerant performances make a strictly positivist approach to the dramatic records of itinerancy impossible. For instance, in Carlisle, payments for minstrels were recorded as such from 2 June 1602-3:

$\begin{array}{ll}\text { Item vnto John grayson waitt of Cothermouthe } & \text { xij d } \\ \ldots & \text { xij d } \\ \text { Item vnto ij Scotes minstrels } & \\ \ldots & \text { vj d } \\ \text { Item vnto John nixon piper } & \\ \ldots & \text { ij } s \\ \text { Item vnto j scotes gentlewomanminstrell } & \text { xiij s iiij d } \\ \text { Item vnto my lorde evers players } & \\ \ldots & \text { iij s iiij d } \\ \text { Item vnto the waittes of lankaster } & \text { x s } 47 \\ \text { Item vnto certeine players in December } & \end{array}$

Whether this is a female Scottish minstrel or the minstrel of a Scottish woman is unclear. And who were the 'certeine players' who performed in December? This record cannot be reduced to a single meaning; both meanings are possible. The ambiguity is unresolvable, a not-uncommon feature of dramatic records. Similarly, the St. Michael Parish Register in Cockerham records the death of two women in such a way that it is unclear whether the women or their husbands were musicians:

\begin{tabular}{|c|c|c|}
\hline 162323 June & $\begin{array}{l}\text { wife of Robert Hodgson } \\
\text { of Ellel, piper }\end{array}$ & buried \\
\hline 1623/4 21 March & Elizabeth, widow & \\
\hline ber & $\begin{array}{l}\text { of Michael Jackson, piper } \\
\text { Janet, daughter of }\end{array}$ & buried \\
\hline & John Jackeson, piper & christenec \\
\hline
\end{tabular}


163216 December

164223 November
Henry, son of Henry, the piper of Pilling christened Elizabeth, daughter of John Haworth, fiddler christened ${ }^{48}$

While the fact that the christened children are described in terms of their father's profession may indicate that the same goes for the wives, this supposition does not efface the possibility that the women could have been pipers themselves, that they could have been married to a piper, or that they were married to a piper and were pipers themselves.

Even assessing which individual performed in a troupe is fraught with difficulty. For instance, many players are listed in the records as performing 'feats of activity'. 'Feats of activity' as Butterworth notes, is a nebulous indicator of the kind of performance enacted, since the term encompasses several practices, including 'juggling, tumbling, vaulting, and dancing on the rope', which were performed by several people. ${ }^{49}$ According to Butterworth, 'these activities and their requisite skills were combined sometimes through individuals and on other occasions through groups, companies or families of jugglers. Because of this multi-skilled ability it is sometimes difficult to separate the skills in order to determine their nature in relation to feats of activity'. ${ }^{50} \mathrm{~A}$ record from the Mayor's Court Books of 9 October 1616 in Norwich presents similar interpretive problems about the nature of the performance enacted:

in the afternoone John De Rue and Ieronimo Galt ffrenchmen brought before mr Maior in the Counsell Chamber A Lycence Dated the $23^{\text {rd }}$ of ffebruary in the xiij $^{\text {th }}$ yeare of the Reigne of Quene Elizabeth \& in the yeare of our Lord 1616 thereby authorisinge the said John De Rue \& Ieronimo Galt ffrenchmen to sett forth \& shewe rare feates of Actiuity with Dancing on the Ropes performed by a woman $\&$ also A Baboone that can doe strange feates, And because the lycence semeth not to be sufficient they are forbidden to play. ${ }^{51}$

From the way in which this act is described, it is possible that the woman who danced on the ropes performed together with the baboon or that the woman rope dancer and the baboon were two separate acts. The record sustains multiple readings and is irreducible to a single meaning, again making a positivist approach problematic.

Simply put, the dramatic records of itinerant performers need to be read differently from the records of text-based drama for the reasons listed above 
and because of the ways in which the dramatic record is entrenched in a specific time and place. Patricia Badir has written about how the dramatic record is grounded in the local and in the body of the performer itself and how it 'reactivates the creative capacities of the body ... reach[ing] outside the confines of discursive forms of knowledge and reinvigorat[ing] the here and now of the playing environment'. ${ }^{52}$ For Badir, the temporality of the performance preserved in the record is evidence of the ways in which theatre can disrupt tactically, in a de Certeauvian sense, its own aims to promote noble, royal, and civic largesse. ${ }^{53}$ The records manifest a challenge to positivism because the documents have a pregnant locality and specificity in their communication of a single reaction and cannot be taken as an uncomplicated representative history. This failure to communicate unbiased 'truth' is, in some ways, the greatest potential of the record. It registers the precise moment of the performance and offers us an entirely different way of reading early modern performance records. We can, I argue, use this potential to recover the political resonances of the individual performances of early modern women itinerants.

\section{Test Case: 'the french woman that had no hands' and the Politics of Itinerant Performance}

The subject of this test case was a freak performer who toured the country in the 1630s. Displaying people with physical differences was a common phenomenon in early modern England, but while it is important to acknowledge the repugnance of the practice, it is similarly important to acknowledge that these people could also be bona fide performers. Katherine Park and Lorraine Daston's discussion of the complex emotions and interpretations that monsters, or freaks, could elicit indicates that various reactions to such people were possible. The reactions Park and Daston outline include seeing monsters as prodigies whose disabilities are a sign of God's wrath, as sources of 'delight and pleasure' when put on show, and as objects of scientific inquiry. ${ }^{54}$ Despite the fact that one of the primary ways in which renaissance audiences perceived the freak was as a show staged for their 'delight and pleasure', very few critics of renaissance freaks are willing to see these individuals as performers. Parolin and Brown, for instance, find that such 'women cannot be seen as players in the agential sense because they were entirely subjected to the violence of representation, experiencing its coercive power without designating or controlling their own display'. 55 One of the records documenting the 
career of 'the french woman that had no hands', however, suggests the possibility for the performance of a 'freak' to move beyond exploitative, exoticist display into a politically challenging theatrical event.

The first record comes from the diary of William Whiteway, a wealthy Puritan and Dorchester merchant. The following is Whiteway's full account of the performer's appearance in Dorchester, written on 5 December 1634: 'Here came a french woman that had no hands, but could write, sow, wash, \& do many other things with her feet: She had a commission under the seale of the Master of the Reuelles. not allowed here' ${ }^{56}$ REED's Norwich volume contains what is most likely another reference to this performer, this time naming her and mentioning her husband, two details absent from the Whiteway record:

This day Adrian Provoe $\&$ his wife brought into this Court A lycence under the Seale of Revelles dated the xij ${ }^{\text {th }}$ of November 1632 whereby she beinge a woman without handes is licenced to shew diverse workes \&c done with her feete, they are lycenced to make their shewes fower dayes. ${ }^{57}$

Although Whiteway does not name the woman he describes as 'the french woman that had no hands' (and it is certainly possible that these women were two separate performers), it is likely given the proximity of the years of performances and the similarity of the acts described that these woman are one and the same. While from here on I choose to refer to Whiteway's 'french woman' as Provoe, at the same time I want to draw attention to the ambiguity in the records.

Provoe, like many other women described in this article, was licensed by the Master of the Revels to perform. Furthermore, if the handless woman in Dorset is the same as the one who appeared in Norwich, she clearly travelled large distances across England. We can surmise that she likely played in cities, towns, villages, and households in between, though I have yet to find other records of her in civic or household accounts. ${ }^{58}$ Whiteway's diary entry reveals that Provoe was not allowed to play in Dorset, but the interdiction of her performance is not remarkable in and of itself, since many performers were turned away from the city at this time. The editors of REED's Dorset volume, Rosalind Conklin Hays and C.E. McGee, write that Puritanism and poor behaviour by touring actors turned Dorset authorities against playing in general. ${ }^{59}$ They note that 'players travelling as the prince's men (see p 198), puppeteers who "had a warrant vnder the King's hand" (see p 200), and Mrs 
Provoe who "had a commission under the seale of the Master of the Revelles" (see p 206) were all summarily dismissed'. ${ }^{60}$ Whether or not Provoe obeyed the orders of the town council not to perform in Dorchester is unknown, but Provoe and her husband did earn the permission to perform for four days in Norwich.

The language used to describe Provoe in both the Whiteway record and the Norwich record merits closer attention. The Norwich record begins with a description of Provoe in terms of her husband, 'Adrian Provoe $\&$ his wife'. This presentation of Provoe as a wife, as a woman who meets normative standards, contradicts the thrust of the rest of the record which emphasizes her disability. The Norwich record reads: 'she beinge a woman without handes is licenced to shew diverse workes \&c done with her feete'. Here, Provoe's 'beinge' encodes her disability at the level of identity. This essentialist description of Provoe as a 'freak' communicates that the only remarkable thing about Provoe is that she can function in spite of her disability in a way that makes her fascinating. The record gives no sense of the kind of act she performed, only registering that she is a 'body on display'. ${ }^{61}$ The record does not enumerate what the 'diverse workes' are that Provoe performs; it mentions vaguely that she does something with her feet, suggesting that the recorder finds it remarkable that she can do anything at all.

The Whiteway record, conversely, describes Provoe in such a way that reveals how her performance had the potential to challenge ideologies of femininity, domesticity, and disability. Whiteway describes Provoe as a French woman with the ability to perform mundane domestic skills in an interesting way. His description of her does not foreground her disability in the same way the Norwich record does. Instead, he describes her as a 'french woman that had no hands, but could write, sow, wash, \& do many other things with her feet'. Whiteway's sentence uses her disability to qualify her essential identity as a French woman. His description of Provoe's disability, moreover, is followed immediately by a description of her ability, most clearly signaled with his use of 'could'. The Norwich record does not allow that her disability could permit a different kind of ability in the way that Whiteway's record does. Finally, Whiteway's record lists in far more detail the nature of Provoe's act than does the Norwich record. In his description of the various abilities she possesses as a result of her disability, Whiteway does more than marvel at the fact that this woman can function; instead he describes her skillful performance of sewing, writing, washing, and doing other activities with her feet. In Whiteway's account, what is remarkable about Provoe is her performance. 
If the Norwich record defuses the radical nature of Provoe's performance by only understanding her as a disabled woman, the Whiteway record registers a real interest in the content of her performance and in what Provoe can do. Whiteway's recognition of Provoe's femininity, his interest in the details of her act, and his use of the language of ability to describe her performance indicates that Provoe's performance may not have always been received as a spectacle of her difference, but instead might have been a performance that challenged the status quo.

Indeed, the Whiteway record of Provoe's performance evinces what Badir describes as 'the potential of the archive' to 'figur[e] by default the illegitimate, the marginal, the masterless, and the non-conformist, whose disruptive appropriation of urban space tactically altered strategic fashionings of both Commonwealth and Commonalty. ${ }^{63}$ Although her act involved the performance of domestic work and everyday projects, Provoe's French origin, handless arms, and extremely dextrous feet transformed the mundane actions she staged into an extraordinary and unfamiliar spectacle, essentially recasting the quotidian as the carnivalesque. Provoe's burlesque of domesticity is a compelling example of the potential of itinerant women's theatre to upset norms and enact cultural anxieties. Her theatre was not simply an exploitative spectacle, but a politically charged challenge to accepted values. Rosemarie Garland-Thomson has written on the link between femininity and disability, arguing that

Disabled women are, of course, a marked and excluded — albeit quite varied group within the larger social class of women. The relative privileges of normative femininity are often denied to disabled women (Fine and Asch 1988). Cultural stereotypes imagine disabled women as asexual, unfit to reproduce, overly dependent, unattractive - as generally removed from the sphere of true womanhood and feminine beauty. ${ }^{64}$

Provoe's assumption of the roles of normative femininity despite her disability questions the very polarities of ability and disability, of normalcy and the abnormal. Her performance of everyday activities calls out for recognition as a part of the everyday, or even better, for a reconsideration of such concepts of the everyday and of the domestic, and criticizes the society that recognizes only her difference. Provoe's performance, instead of being a presentation of difference which reinforces norms, radically confronts that difference and pleads for her recognition as a woman and not as a freak. That 
she was licensed by the state to perform this act and made a living doing so is all the more remarkable and goes a long way towards demonstrating the political potential of women's professional theatre before 1660. Provoe had a sanctioned space within the culture, and she transformed that space into a performance in which she addressed the circumstances of her day-to-day life. Whether or not Provoe's audiences saw the act as politically motivated or as an exploitative spectacle of difference, the potential for such radical interpretations of her performance is inherent in Whiteway's record. In the Whiteway record, we can glimpse what Whiteway and the other town officials saw in the moment of her performance for them in 1634. The town officials were perhaps the only people in Dorset (but certainly not in England) to witness Provoe's powerful interrogation of the very norms of the culture. Whiteway's record has the ability to bring us back to that moment and recall for us the important political work Provoe's act had the potential to accomplish.

As more REED volumes are published and as more household accounts of women's performances are unearthed, we can only add to our knowledge of the ways in which women performed professionally. Yet no matter how much we recover we will never completely recover the full performance history of itinerant performers. Nor can we in the face of such a rich tradition limit the performances of early modern women and the political potential of their performances. Benjamin writes in the 'Theses on the Philosophy of History' that 'the true picture of the past flits by. The past can be seized only as an image which flashes up at the instant when it can be recognized and is never seen again'. ${ }^{65}$ Further archival discoveries might bring us more of these 'flashes' of the past, but this need not be seen as a failure of the genre or as an indicator of its insignificance. Instead, such temporality constitutes evidence of the tremendous potential of this performance tradition to disrupt ideological structures. The 'flash' of the political performance of Provoe in Whiteway's description recovers the possibility that her performance career was not one merely of exploitation but of a real political challenge. Positivism can help us to recover early modern women's touring practices, but only by reading the records outside of this methodology can we access the power of these women's performances. 


\section{Notes}

I would like to thank Marta Straznicky, Lindsey Banco, Leslie Ritchie, Helen Ostovich, and the anonymous readers of Early Theatre for their help with this article. I would also like to thank the Social Sciences and Humanities Research Council of Canada and Queen's University for supporting my research.

1 There have been few articles which examine women's touring practices. Thornton Shirley Graves, Women on the pre-restoration stage', Studies in Philology 22.2 (1925), 184-97, surveys some of the evidence of women's performances of all kinds, amateur and professional. Ann Thompson, 'Women, 'women,' and the stage,' Women and Literature in Britain, 1500-1700, Helen Wilcox (ed.) (Cambridge, 1996), 104, lists some of the ways that early modern women participated in the touring culture of early modern England in her larger discussion of the various manifestations of women's theatre before 1660: they were paid for singing, dancing, and playing musical instruments; they were exhibited as freaks, and they were granted licenses to exhibit freaks'. Mark Thornton Burnett, Constructing 'Monsters' in Shakespearean Drama and Early Modern Culture (Houndmills, 2002), 8-32, also writes on the careers of men and women who were displayed in theatres, fairs, focusing especially on the pamphlets circulated about these performers. James Stokes, Women and Mimesis in Medieval and Renaissance Somerset (and Beyond)', Comparative Drama 27.2 (1993), 179, writes a more thorough account of women itinerants in his description of women's performances in Somerset in general, noting that, in that county at least, the idea of women entertainers operating in the county in the early seventeenth century was quite acceptable'.

2 Such critics include M.A. Katritzky, Women, Medicine, and Theatre, 1500-1750: Literary Mountebanks and Performing Quacks (Aldershot, 2007), and Bella Mirabella "Quacking Delilahs": Female Mountebanks in Early Modern England and Italy,' Women Players in England, 1500-1660: Beyond the All-Male Stage, Pamela Allen Brown and Peter Parolin (eds) (Aldershot, 2005), 89-108. Ann Thompson, James Stokes, and the essays published in Pamela Allen Brown and Peter Parolin's Women Players in England, 1500-1660 all discuss women's wide-ranging involvement in the early modern theatre, both amateur and professional. Natasha Korda, The Case of Moll Frith: Women's Work and the "All-Male Stage"', Brown and Parolin (eds), 71-88, and 'Women's theatrical properties', Staged Properties in Early Modern English Drama, Jonathan Gil Harris and Natasha Korda (eds) (Cambridge, 2002), 202-29, examines women's imbrication in the economies surrounding the London stages, 
expanding our conception of the ways in which women were involved in London's performance cultures.

3 For criticisms of REED's positivism see Patricia Badir, Playing Space: History, the Body, and Records of Early English Drama', Exemplaria 9 (1997), 255-79; Theresa Coletti, Reading REeD: History and the Records of Early English Drama', Literary Practice and Social Change in Britain 1380-1530, Lee Patterson (ed.) (Berkeley: U of California P, 1990), 248-84.

4 One could, presumably, search by event or venue, but such a search requires that one knows what to look for. See http://link.library.utoronto.ca/REeD/.

5 Henry Farley, St Paules-Church her Bill for Parliament (1621) sTC / 790:11. Farley's work was presented to King James to promote the interests of the church. The complaint was actually part of an entertainment presented to the king at Christmas after his return from Scotland (E3) and is spoken by a character named Zeale. For further discussion of the complaint, see N.W. Bawcutt, The Control and Censorship of Caroline Drama: The Records of Sir Henry Herbert, Master of the Revels 1623-73 (Oxford, 1996), 77-8. Farley's entertainment was probably never performed.

6 Joyce Jeffries, A NEW BOOKE OF RECEIGHTS of Rents Anueties and Interest moneys begining at St Mary day 1638 written at Heryford, at John Fletchers howse, BL Egerton 3054, 36-9b.

7 David Galloway (ed.), REED: Norwich 1540-1642 (Toronto, 1984), 227.

8 Bawcutt, The Control and Censorship of Caroline Drama, 142.

9 Stokes, Women and Mimesis,' 179.

10 Bawcutt, The Control and Censorship of Caroline Drama, 142.

11 Ibid, 154.

12 The word 'freak' generally has derogatory connotations. I use it here self-consciously not to rehearse these connotations but to describe the kinds of performances enacted. The word freak in this essay should therefore be understood as if it is always written in scare quotes. My understanding of freaks as performers is informed by Robert Bogdan, The Social Construction of Freaks', Freakery: Cultural Spectacles of the Extraordinary Body, Rosemary Garland- Thomson (ed.) (New York, 1996), 23-37. Bogdan examines carnival performers in the late nineteenth- and early twentiethcentury United States. Bogdan's argument, of course, is a historically situated one, but the highly theatrical nature of the display of freaks in the early modern period, as Burnett notes as well in Constructing 'Monsters', 10, makes the designation applicable to early modern freak performers as well.

13 Galloway (ed.), REED: Norwich, 156-7.

14 Bawcutt, The Control and Censorship of Caroline Drama, 77.

15 John R. Elliot and Alan H. Nelson (eds), REED:Oxford (Toronto, 2004), 490. 
16 Much information survives about Urslerin and a significant amount of work has been done on her long career. See Philip H. Highfill Jr., Kalman A. Burnim, and Edward Langhans, A Biographical Dictionary of Actors, Actresses, Musicians, Dancers, Managers, and Other Stage Personnel in London, 1660-1800 (Carbondale and Edwardsville, 1993), 15.103-4; Burnett, Constructing 'Monsters', 16-7; Mark Albert Johnston, Bearded Women in Early Modern England', SEL 47.1 (2007) 1-28; and Katrizky, Women, 2-4.

17 Bawcutt, The Control and Censorship of Caroline Drama, 83. In rare instances, royal patents were granted to itinerants. One of these was granted to the Genovese Siamese twins, Lazarus and Baptista Colloretti or Colloredo. Lazarus was attached to Baptista's navel, and the two became celebrities. '[P]oems were written about them', and they were the subjects of 'medical treatises'. See 81.

18 See Paola Pugiliatti, Beggary and Theatre in Early Modern England (Aldershot, 2003), 2-3 for more on attempts to contain touring players which date back to the thirteenth century.

19 Leeds Barroll, Alexander Leggat, Richard Hosley, and Alvin Kernan, The Revels History of Drama in English: Volume III, 1576-1613 (London: Methuen, 1975), 9.

20 Bawcutt, The Control and Censorship of Caroline Drama, 41.

21 Ibid, 173.

22 Peter Greenfield, Touring', A New History of Early English Drama, John D. Cox and David Scott Kastan (eds), (New York, 1997), 257-68.

23 Ibid, 258-9.

24 Ibid, 261.

25 Many European licenses survive, but few of them list women performers. More work needs to be done to address this disjunction.

26 Bawcutt, The Control and Censorship of Caroline Drama, 308-9.

27 Ibid, 309.

28 Ibid, 80; Philip Butterworth, Magic on the Early English Stage (Cambridge, 2005), $30-1$.

29 Ibid, 30-1. Butterworth lists the some of the records relating to the Peadles' from when the records begin in 1608 in Leyden; it is clear from these earlier records that William Peadle was in charge at this time.

30 Galloway (ed.), REED: Norwich, 142.

31 Ibid, 126.

32 Stokes, Women and Mimesis', 178.

33 Ibid, 180. 
34 Michael Shapiro, 'The Introduction of Actresses in England: Delay or Defensiveness?', Enacting Gender on the English Renaissance Stage, Viviana Comensoli and Anne Russell (eds), (Urbana and Chicago, 1999), 192.

35 James Stokes and Robert J. Alexander (eds), REED: Somerset, including Bath (Toronto, 1996), 495-6.

36 John R. Douglas and Peter Greenfield (eds), REED: Cumberland, Westmorland, Gloucestershire (Toronto, 1986), 359.

37 Klausner (ed.), REED: Herefordshire, Worchestershire (Toronto, 1990), 197.

38 Ibid, 190-1.

39 David George (ed.), REED: Lancashire (Toronto, 1991), 244. In 1587, The House and Farm Accounts of the Shuttleworths of Gawthorpe Hall, John Harland (ed.) in Remains Historical and Literary Connected with the Palatine Counties of Lancaster and Chester, Parts 1-4 (Manchester, 1856-8) records a payment to "Ellen Throppe the dey [dairy keeper] for a quarter and a forte night services" (40); earlier in that year, the Shuttleworth accounts record a payment to "a musicione of Mr. Athertones” (39), who could possibly be Thropp herself, though this is not verifiable. If Thropp was the musician, she would have worked as fool to Atherton, temporary dairy keeper to the Shuttleworth's, and, possibly, as a musician paid by the Shuttleworth's as well over the course of her lifetime.

40 Barbara Palmer, Early Modern Mobility: Players, Payments, and Patrons', Shakespeare Quarterly 56.3 (2005), 262.

41 Broadsheets survive which provide details of performers such as Tannakin Skinker. See $A$ Certaine relation of the hog-faced gentlewoman called Mistris Tannakin Skinker, STC 22627.5 (1640). A broadsheet, however, is not a script. The improvisational nature of itinerant performance makes even these an inadequate record of the performance event.

42 Andrew Gurr, The loss of records for the travelling companies in Stuart times', Records of Early English Drama Newsletter 19.2 (1994), 3.

43 Ibid, 4.

44 See James Gibson's 'Stuart Players in Kent: fact or fiction?' Records of Early English Drama Newsletter 20.2 (1995), 2. Gibson refutes Gurr's reading, arguing that playing did, in fact, decline in Kent in Stuart and Caroline England. See also Greenfield, 'Touring,' 265.

45 Gurr, 'The loss of records,' 6.

46 Bawcutt, The Control and Censorship of Caroline Drama, 76. As Bawcutt outlines, most of the examples which survive come from Ord's transcript, though HalliwellPhillipps did not keep this transcript in tact, further limiting the number of documents which survive. 
47 Audrey Douglas and Peter Greenfield (eds), REED: Cumberland, Westmorland, and Gloucestershire (Toronto 1986), 66.

48 David George (ed.), REED: Lancashire, 243.

49 Butterworth, Magic, 26.

50 Ibid, 26.

51 Galloway (ed.), REED: Norwich, 150.

52 Badir, Playing Space'. 275-6.

53 Michel de Certeau, The Practice of Everyday Life, Trans. Stephen Randall (Berkeley, 1984). De Certeau distinguishes between tactic and the strategy as means of political action in The Practice of Everyday Life. 'A tactic', he writes, 'insinuates itself onto the other's place, fragmentarily, without taking it over in its entirety, without being able to keep it at a distance. It has at its disposal no base where it can capitalize on its advantages, prepare its expansions, and secure independence with respect to circumstances ... because it does not have a place, a tactic depends on time - it is always on the watch for opportunities that must be seized 'on the wing.' Whatever it wins, it does not keep (xix) . Conversely, a strategy 'assumes a place that can be circumscribed as proper (propre) and thus serves as the basis for generating relations with an exterior distinct from it' (xix). The strategy is connected to power, the idea of the 'proper', and the institution, and hence is a less radical form of practice.

54 Lorraine Daston and Katherine Park, Wonders and the Order of Nature, 1150-1750 (New York, 1998), 176. For more on the pleasure of viewing monsters, see 190-201.

55 Brown and Parolin, "Introduction," Women Players in England, 1500-1660: Beyond the All-Male Stage, Brown and Parolin (eds) (Aldershot, 2005), 8. One exception is Burnett who does so in his discussion of the entertainment industry surrounding the display of people for their physical or performed difference. He writes that: If, in the contemporary puritan sensibility, fairground "monsters" and playhouse actors traversed a comparable ideological terrain, this may have been at least in part because they worked with similar material arenas. Jeffrey D. Mason has argued that "the street fair as a site or venue is comparable to the theatrical stage”, emphasizing the parallel behaviors of the participants at each event' (10).

56 Rosalind Conklin Hays and C.E. McGee / Sally L. Joyce and Evelyn S. Newlyn (eds), REED: Dorset / Cornwall (Toronto, 1999), 206.

57 Galloway (ed.), REED: Norwich, 211.

58 A reference to Provoe, or another cognate performer, appears in Jasper Mayne's The City Match, a Comoedy (1659) Wing / 871:02. In the play, characters speculate on the audience appeal of a fish as opposed to the acts on show in London at the time: The Birds / Brought from Peru, the hairy Wench, the Camell, / The Elephant, Dromedarie, 
or Winsor Castle, / The Woman with dead flesh, or She that washes / Threads needles, writes, dresses her children, plaies / Oth'Virginalls with her feet' (26). I thank the anonymous reader for drawing this reference to my attention. See also Graves, 'Women', 187.

59 Hays and McGee (eds), REED: Dorset, 46.

60 Ibid, 46-7.

61 Rosemarie Garland-Thomson uses the term body on display' to describe the display of women in the nineteenth century like Saartje Baartman, who was commonly known as the Hottentot Venus, and Jula Pastrana, who was marketed as The Ugliest Woman in the World'. See Extraordinary Bodies: Figuring Physical Disability in American Culture and Literature (New York, 1997), 51.

63 Badir, Playing Space', 276.

64 Rosemarie Garland-Thomson, Integrating Disability, Transforming Feminist Theory', The Disability Studies Reader, $2^{\text {nd }}$ ed., Lennard J. Davis (ed.) (New York, 2006), 266.

65 Walter Benjamin, Thesis on the Philosophy of History', Illuminations, Harry Zohn (trans), Hannah Arendt (ed.) (New York: Shocken, 1968), 255. 